\begin{tabular}{c} 
OSOBA I WOLA \\
Filozofia Chrześcijańska $\bullet$ Tom 10, Poznań 2013 \\
Uniwersytet im. Adama Mickiewicza w Poznaniu $\bullet$ Wydział Teologiczny \\
\hline
\end{tabular}

\author{
HENRYK GASIUL \\ Uniwersytet Kardynała Stefana Wyszyńskiego \\ Wydział Filozofii Chrześcijańskiej \\ Instytut Psychologii \\ Katedra Psychologii Osobowości
}

\title{
Wybrane sposoby interpretacji procesów wolicjonalnych i wolności woli we współczesnej psychologii. Realizacja motywów ja jako podstawa rozwoju dyspozycji wolicjonalnych
}

Selected Models of Interpretation of Volition Process and Freedom of Will in Contemporary Psychology. Fulfillment of Self-motives as a Base of Development of Volitional Dispositions

Prezentowany artykuł jest próbą ukazania dominujących we współczesnej psychologii sposobów interpretacji procesów wolicjonalnych i problemu wolności woli. Wolność woli jest bardzo trudnym, choć powszechnie doświadczanym stanem. Autorowi chodzi o odpowiedź na pytanie, jakie czynniki czy też warunki stają się istotne dla stworzenia dyspozycji do rozwoju sprawności woli oraz stawania się coraz bardziej podmiotem osobowym dysponującym własną wolnością.

\section{WOLNOŚĆ WOLI Z PERSPEKTYWY PSYCHOLOGII WSPÓłCZESNEJ - WYBRANE INTERPRETACJE}

Współczesna psychologia stara się unikać pojęcia woli, a zwłaszcza wolności woli. Przyczyną takiego stanu rzeczy jest z jednej strony wyraźna potrzeba traktowania psychologii jako nauki empirycznej, a z drugiej pojawienie się nowych, deterministycznych tendencji interpretacyjnych - począwszy od teorii Darwina, w której styl interpretacji pozwalał na inną niż dotychczas perspektywę analizy zjawisk psychicznych. Pojęcie woli stało się czymś nienaukowym, a zjawiska wolicjonalne traktowano jako perceptualne złudzenia. Co ciekawe, 
właściwie psychologia niemiecka, która jest traktowana jako kolebka współczesnej psychologii, nie rezygnowała z pojęcia wolności woli i samej woli (akty wolicjonalne były podkreślane przez Wilhelma Wundta, Oswalda Kuelpego, przez Roberta Acha zajmującego się psychologią woli). Pojęcie woli i wolności woli zastapiono pojęciami motywacji i motywów, potrzeb i kontroli. Jak podkreśla Rollo May „[...] nowy akcent na «kontrolę umysłu i osobowości», jako zaprzeczenie wolności osoby, jest chyba najbardziej widoczny w akademickiej psychologii"'. Niemniej jednak pojawiają się próby powrotu do znaczenia woli, lecz z nieco innej perspektywy. Często wolę traktuje się jako łańcuch decyzyjny, który poddaje się kontroli eksperymentalnej - co znajduje potwierdzenie w badaniach $\mathrm{z}$ kręgu neuronauki ${ }^{2}$ - lub jako zachowania intencjonalne ${ }^{3}$.

Współcześnie wolność woli jest najczęściej analizowana w kategoriach procesów samoregulacyjnych, które pozwalają na przestrzeganie zasad determinizmu. Wybór zachowania, który może być subiektywnie doświadczany jako poczucie wolności woli, z reguły ma swoje wcześniejsze uwarunkowania (jak doświadczenia wyniesione $\mathrm{z}$ dzieciństwa, poziom rozwoju poznawczego itd.). Pojawienie się sytuacji, w której następuje wybór, jest z kolei warunkowane stanami mózgu, rodzajem wzbudzonych motywów, właściwościami bodźca czy sytuacji. Dalej pojawia się kwestia jednostkowych decyzji uzależniona od rodzaju wzbudzonych procesów poznawczych, ocena wagi alternatyw, rozważenia różnych opcji i wybór działania. Po wykonaniu działania pojawia się faza postdecyzyjnej oceny trafności wyboru. Pętla się zamyka.

Patrząc z perspektywy społeczno-poznawczej, warto zauważyć, że procesy samoregulacyjne przebiegają w trzech cyklicznych fazach, którymi są: przezorność (forethought), wykonanie lub wolicjonalna kontrola oraz proces samorefleksji. Przezorność odnosi się do tych procesów, które wpływają na wysiłki na rzecz działania i poprzedzają je. Wykonanie lub kontrola wolicjonalna angażuje procesy, które występują w trakcie wysiłków motorycznych, emocjonalnej uwagi i działania. Samorefleksja wreszcie to procesy występujące po zaangażowaniu na rzecz wykonania i związane $\mathrm{z}$ gromadzeniem doświadczeń w zakresie sposobów reagowania. Zwrotnie, procesy samorefleksyjne wpływają na przezorność.

R. May, Psychologia i dylemat ludzki, Warszawa 1989, s. 192.

${ }^{2}$ Por. np. P. Haggard, Human volition: towards a neuroscience of will, "Nature" 2008, 9, s. 934-946.

${ }^{3}$ Por. np. J. Barresi, C. Moore, Intentional relations and social understanding, "Behavioral and Brain Sciences" 1996, 19, 1, s. 107-154; D. Dannefer, Freedom isn't free. Power, alienation, and consequences of action, w: Action \& self-development. Theory and research through the life span, red. J. Brandtstadter, R.M. Lerner, Thousand Oaks 1999, s. 105-131; K. Obuchowski, Człowiek intencjonalny, Warszawa 1993; E. Pacherie, The phenomenology of action: a conceptual framework, "Cognition" 2008, 107, s. 179-217. 
Ważna jest także koncentracja uwagi na sobie samym - ona bowiem wpływa, poprzez procesy porównywania aktualnych zachowań ze standardami, na samoregulację. Celem zachowania samoregulacyjnego jest $\mathrm{z}$ reguły zmniejszanie rozbieżności pomiędzy idealnymi czy oczekiwanymi zachowaniami a zachowaniem aktualnym. Na zmiany w zachowaniu wpływa ponadto zestawienie pozytywnych i negatywnych oczekiwań - mają one zminimalizować zaistniałe rozbieżności w ramach standardów ,ja" i pozwolić na utrzymanie obrazu siebie (self-image). Teorie rozbieżności standardów ,ja” pokazują wiele zależności w tym wymiarze - one też akcentują indywidualność człowieka (porównywanie następuje w ramach niezależnych, jednostkowych standardów czy oczekiwań) ${ }^{4}$.

Interesująca jest także w tym względzie interpretacja Juliusa Kuhla. Proponuje on odróżnienie tego, co można nazwać motywacją wyboru, od motywacji realizacji (która jest w istocie motywacją wolicjonalną). Motywacja wyboru zawiera w sobie takie procesy psychiczne, które określają rodzaj wybieranego do realizacji działania, natomiast motywacja realizacji dotyczy procesów, które zapewniają wykonywanie działania pomimo różnych oporów, trudności etc. ${ }^{5} \mathrm{~W}$ innym miejscu J. Kuhl ${ }^{6}$ sprowadza motywację realizacji do procesu samoregulacji, a motywację wyboru do procesu samokontroli. Samoregulacja jest zasadniczo czymś nieświadomym i polega na równoczesnym przetwarzaniu oraz koordynacji informacji dopływających z różnych wewnętrznych systemów (tj. uczuć, przekonań, wartości, potrzeb) oraz z otoczenia. Z kolei samokontrola jest raczej czymś świadomym, werbalnie wyrażalnym, działającym w sposób analityczny i sekwencyjny.

Jak to metaforycznie ujmuje Kuhl, samoregulacja jest swego rodzaju ,wewnętrzną demokracją", w ramach której pojawia się wiele, czasami sprzecznych, głosów - jak na przykład własne uczucia, postawy innych, wartości itd. Te wewnętrzne i zewnętrzne głosy przyczyniają się do wzbudzenia woli, prowadzącej do decyzji, która jest następnie wdrażana przez „rząd”. Integracja wszystkich istotnych doświadczeń zapewnia wysoki poziom elastyczności i twórczości w zachowaniach. Pod tym względem koncepcja samoregulacji jest porównywalna do pojęcia twórczej woli i prężności ego zapewniającej właściwy dla danej sytuacji poziom jego kontroli ${ }^{7}$. Integracja własnych ukrytych motywów jest przykładem samoregulacji analizowanej w kategoriach zbieżnych z ,ja” działań, która godzi ze sobą potrzeby i wymagania społeczne (normy kulturowe) oraz po-

\footnotetext{
${ }^{4}$ Za T. Jackson, J. Mackenzie, S.E. Hobfoll, Communal aspects of self-regulation, w: Handbook of self-regulation, red. M. Boekaerts, P.R. Pintrich, M. Zeidner, San Diego 2000, s. 275-300.

${ }^{5}$ Za F. Rheinberg, Psychologia motywacji, Kraków 2006, s. 180.

${ }^{6} \mathrm{~J}$. Kuhl, Individual differences in self- regulation, w: Motivation and action, red. J. Heckhausen, H. Heckhausen, Cambridge 2012, s. 300-328.

${ }^{7}$ Por. teoria Jack i Jeanne Block w H. Gasiul, Psychologia osobowości. Nurty, teorie, koncepcje, Warszawa 2012, s. 304-305.
} 
trzeby innych (altruizm), zamiast konstruowania niekompatybilnych sprzeczności (jak analityczne ego). Gdy świadome koncepcje samego siebie są kongruentne z nieświadomymi motywami, zwiększa się dobrostan (dobre samopoczucie) i obniża się ryzyko zaburzeń psychosomatycznych ${ }^{8}$. Gwoli wyjaśnienia, u Kuhla motywy jawne (explicit motives) to cele działania dostępne $\mathrm{w}$ introspekcji albo motywacyjne koncepcje samego siebie, natomiast motywy ukryte (implict motives), jak na przykład dążenie do osiagnięć, afiliacji, mocy, pozostają z reguły poza świadomym doświadczeniem. Zgodność pomiędzy tymi dwoma systemami motywów wydaje się u wielu ludzi niska.

Falko Rheinberg proponuje uwzględnienie dodatkowych elementów, a mianowicie podział fazy wolicjonalnej na przeddziałaniową i działaniową . Pomiędzy tymi fazami należy ulokować decyzję o realizacji danej intencji. To, która z intencji może lub ma być realizowana, zależy od aktualnej sytuacji, w jakiej znajduje się człowiek. Poza intencją ważne są takie czynniki jak tendencja fiat (niech się stanie) decydująca o rozpoczęciu działania oraz tendencja fazit określająca, w jakiej mierze dane pragnienie jest już rozważone jako coś gotowego do realizacji. Faza działania jest podporządkowana celowi, na który ukierunkowana jest intencja. Oczywiście cele mogą być różne, te nawykowe i proste są łatwiej realizowane, trudniejsze wymagają bardziej złożonych działań. Po zakończeniu działania następuje ocena - co jest typowym schematem interpretacji w psychologicznych analizach (teorie samoregulacji wskazują na fazowość takiego cyklu zachowań). Ale ocena jednocześnie oznacza, czy jeśli cel nie został osiaggnięty, należy dalej do jego realizacji dążyć, czy też zrezygnować, stawiając sobie nowe cele. To jednak wymaga nowego wysiłku woli. Tutaj jest właśnie miejsce na wolę jako pewnego rodzaju jednostkową dyspozycję. W przypadku realizacji celu i związanych z tym pozytywnych odczuć ponowne pojawienie się danego typu sytuacji nie będzie już wymagało jakiegoś szczególnego wysiłku wolicjonalnego. Te osiagane cele same w sobie będą już motywacyjnie atrakcyjne. Można zatem odróżnić od siebie sytuacje, w których zachowanie podlega motywacji, od sytuacji, które wymagają udziału woli. Podleganie motywacji oznacza zgodność podejmowanych działań z własnymi potrzebami, wola oznacza podejmowanie działań, które nie muszą być zgodne z naszymi motywami. Wola wymaga rozmyślnego sterowania i kontrolowania zachowaniami własnymi. Jej aktywność nie musi być związana z odczuciami pozytywnymi emocjonalnie. Generalizując, można powiedzieć, że procesy motywacyjne same w sobie są podporządkowane zasadzie dążenia do przyjemności i unikania przykrości; procesy wolicjonalne są raczej związane z uaktywnieniem zachowań, które mają doprowadzić do osiagania zamierzonego lub stanowionego celu - wtedy to też

\footnotetext{
${ }^{8}$ J. Kuhl, Individual differences in self-regulation, dz. cyt., s. 311.

${ }^{9}$ F. Rheinberg, Psychologia motywacji, Kraków 2006, s. 186-187.
} 
może być dość sprzeczne z zasadą hedonizmu. Niemniej jednak, jeśli poprzez akt woli osiaga się pewne cele, $\mathrm{z}$ czasem one same w sobie są już motywami. Na przykład, porzucenie palenia papierosów wymaga aktu woli; samo bowiem w sobie palenie jest motywem (prowadzącym do odczucia przyjemności); jeśli ten akt woli doprowadzi do porzucenia palenia i niepalenie staje się swego rodzaju poczuciem przyjemności, wówczas niepalenie samo w sobie staje się motywem i nie wymaga już aktu woli. Innymi słowy, motywy ze swej istoty są podporządkowane zasadzie dążenia do przyjemności i unikania przykrości, natomiast zachowania wolicjonalne mają same w sobie wymiar osobistej, podmiotowej decyzji ukierunkowującej (bez względu na to z jakich przyczyn) na podejmowanie zachowań zgodnych z pewnymi osobistymi oczekiwaniami.

\section{OGRANICZONOŚĆ INTERPRETACII WOLI ORAZ WOLNOŚCI WOLI W KATEGORIACH DECYZJI I INTENCJI}

Traktowanie woli tylko jako łańcucha decyzji lub jako intencji nie zawsze spotyka się z aprobata, szczególnie bardziej filozoficznie zorientowanych teoretyków. Na przykład Jing Zhu sądzi, że wola nie da się zredukować do intencji ${ }^{10}$. Wola jest specjalnym rodzajem umysłowego działania, poprzez które podmiot aktywnie i świadomie wiąże ze sobą zastanowienie (deliberation), decyzję i działanie. Pomiędzy tymi elementami istnieją wyraźne luki, które są źródłem pojawienia się w tradycyjnej filozofii problemu wolności woli oraz odniesienia do umysłowej aktywności tradycyjnie określanej mianem woli. Te luki są zapełniane przez podmiot, który ma je połączyć. W „zastanawianiu” podmiot pasywnie nie podlega jakimś chęciom, przekonaniom, które wpłyną na decyzje - podmiot jest aktywny (choć może się kierować pragnieniami itd., to jest zawsze aktywny). W podejmowaniu decyzji podmiot dokonuje swoistej selekcji racji, dlaczego ta, a nie inna. I to właśnie podejmowanie decyzji może być rozumiane jako akt chcenia, po prostu woli. Odniesienie do woli uzasadnia też przechodzenie od decyzji do działania. Można przecież mieć intencję (i podjać decyzję) wykonania pewnego aktu działania, ale ta decyzja czy intencja pozostaje nadal tylko w świadomości jednostkowej do momentu, aż nie zostanie wzbudzony sam akt działania. Nie wykonujemy wszystkich swoich intencji, choć mamy je w świadomości - wielu z nas doświadcza akrasji (słabości woli) - intencja istnieje, ale człowiek nie jest w stanie jej realizować. Dlatego wolę można traktować jako proces pośredniczący, dzięki któremu podmiot wykonuje zamierzone, intencją poprzedzone, działanie. Wykonanie intencji wymaga też kontroli wykonania czy jest ono możliwe, czy też nie, czy w danej sytuacji, czy w innej. Jak podkreś-

${ }^{10}$ J. Zhu, Intention and volition, "Canadian Journal of Philosophy" 2004, 34, 2, s. 175-194. 
la Zhu, trzy różne typy umysłowej aktywności, tj. podejmowanie decyzji, świadoma inicjacja działania, kontrola wykonania wdrażanej intencji, mieszczą się w kategorii określonej jako wola. Wszystkie te trzy formy są bowiem istotne dla wskazania na jedność podmiotowości (unity of agency). Bycie podmiotem oznacza bycie zdolnym do intencjonalnego wykonywania działań. Integralność podmiotowości byłaby zasadniczo niepełna, gdyby podmiot nie był w stanie podejmować decyzji czy dokonywać wyborów i wykonywać działania zgodnie z własną wolą. Ponadto, te trzy formy umysłowej aktywności są tradycyjnie już wiązane z pojęciem woli (chcenia). Luka pomiędzy racją na rzecz działania a decyzją działania to miejsce dla „wolności chcenia”. Jest ona jednocześnie źródłem poczucia bycia podmiotem. Inne luki, pomiędzy intencją a właściwym działaniem i wypełnieniem intencjonalnego działania, wskazują raczej na siłę woli. Można byłoby powiedzieć, że wola to akt umysłu, natomiast intencja jest czasowo utrzymującym się i ukierunkowującym działania stanem umysłu. Wydaje się, że intencja zawiera w sobie wymiar motywacyjny, choć motywem nie jest. Intencje nie są wystarczające do spowodowania zamierzonego działania ${ }^{11}$.

\section{III. "IA" PODMIOTOWE SPRAWCA I DYSPONENTEM WOLI}

Relacja pomiędzy intencją i działaniem jest bardzo złożona, ale jej analiza pozwala na wskazanie kategorii ontologicznej. Uwzględniając powyższe, jak i inne współcześnie tylko wybrane interpretacje, można przyjąć, że zachowanie jest traktowane jako działanie wyłącznie wtedy, gdy ma swoje psychologiczne przyczyny, a przede wszystkim gdy mamy do czynienia z „zapodmiotowieniem” tego działania. Patrząc nawet $\mathrm{z}$ punktu widzenia współcześnie dominującej interpretacji zachowań wolicjonalnych $\mathrm{w}$ kategoriach samoregulacyjnych, można dowodzić, że kluczowe znaczenie ma tutaj sam podmiot. Poza wyżej wzmiankowaną już wagą kongruencji pomiędzy działaniami ,ja" i potrzebami czy wymaganiami zewnętrznymi (interpretacja Kuhla) przykładem podkreślającym wage podmiotu-sprawcy są też inne interpretacje samoregulacyjne. Często podkreśla się tutaj znaczenie kierowania czy zarządzania samym sobą (self-management). To jest funkcja, która inicjuje plany i działania na rzecz upragnionych celów. Kierowanie sobą składa się ze zdolności skutecznego integrowania ze sobą trzech komponentów samoregulacji: (a) właściwego identyfikowania problemu, formułowania dokładnej umysłowej reprezentacji zdarzenia, planowanego zachowania zgodnie z jemu odpowiadającą informacją; (b) poznawczej implementacji (implement) aktywności w sposób, który będzie promował osobisty sukces i zadowolenie; (c) monitorowania i szacowania wewnętrznego i zewnętrznego sprzężenia

\footnotetext{
${ }^{11}$ Tamże.
} 
zwrotnego wykonywanego zachowania z napotykanymi zobowiązaniami i powinnościami. Niezdolność do kierowania zachowaniem uwzględniająca wymienione komponenty związana jest ze słabością kierowania sobą i szybką rezygnacją z dążenia do upragnionych celów ${ }^{12}$.

Powyższe w podstawowej mierze zwraca uwagę na znaczenie poczucia podmiotowości. Różne są sposoby analizy poczucia podmiotowości. Na przykład, Elisabeth Pacherie ${ }^{13}$ wymienia wśród wymiarów składających się na poczucie podmiotowości: (a) poczucie intencjonalności (podmiot jest przyczyną danego działania); (b) poczucie inicjatywności (ja inicjuję dane działanie); (c) poczucie kontroli (czasem inicjuje dane działanie, lecz nie kontroluję jego przebiegu). Albert Bandura wskazuje na: (a) intencjonalność (traktowaną jako podmiotowa zdolność angażowania się na rzecz działań); (b) dalekosiężne przewidywanie (zdolność przewidywania konsekwencji odległych celów, nadająca życiu kierunek i sens); (c) samoregulację (zdolność do korygowania zachowań poprzez porównanie ze standardami i celami osobistymi); (d) autorefleksyjność (zdolność do refleksji nad samym soba) ${ }^{14}$. Jak podkreśla przy tym A. Bandura ${ }^{15}$, bycie podmiotem wymaga wysiłku, swoistego ćwiczenia, często bowiem człowiek może rezygnować $\mathrm{z}$ dążenia do osiagania osobistej podmiotowości na rzecz podmiotowości z upoważnienia.

Interesujące są analizy poczucia podmiotowości i inicjatywności oraz działania zaprezentowane przez Giuseppe Riva ${ }^{16}$. Są to analizy nad „obecnością presence". Obecność pełni podwójną funkcję: (a) lokuje ,ja” (self) w zewnętrznej fizycznej i/albo kulturowej przestrzeni - self jest obecny w przestrzeni, jeśli może w niej działać; (b) obecność zwrotnie informuje ,ja” (self) o jego statusie działalności - ,ja” (self) postrzega zmiany w obecności i ustawia zgodnie z nimi swoją działalność.

Obecność może być traktowana jako złożona, choć nie zawsze w pełni świadoma forma monitorowania działania i doświadczenia, jest uchwytna dla ,ja” (self) i rozstrzyga o jego istnieniu. Zasadniczym, doświadczanym rezultatem tego procesu jest poczucie podmiotowości - poczucie, że jesteśmy zarówno autorami, jak i właścicielami własnych działań. $Z$ tego powodu uczucie obecności nie jest czymś oddzielnym od doświadczenia podmiotu, ale jest związane z podmiotowością. Wyraźniejszy poziom doświadczanej obecności wiąże się z lepszą jako-

${ }^{12}$ Por. T. Jackson, J. Mackenzie, S.E. Hobfoll, Communal aspects of self-regulation, w: Handbook of self-regulation, red. M. Boekaerts, P.R. Pintrich, M. Zeidner, San Diego 2000, s. 277-279.

${ }^{13}$ E. Pacherie, The phenomenology of action: a conceptual framework, "Cognition" 2008, 107, s. $179-217$.

${ }^{14}$ Por. P. Oleś, Wprowadzenie do psychologii osobowości, Warszawa 2003, s. 226-227.

15 A. Bandura, Exercise of human agency through collective efficacy, w: The Personality Reader, red. M.W. Schustack, H.S. Friedman, Boston 2008², s. 190-194.

${ }^{16}$ G. Riva, J.A. Waterworth, E.L. Waterworth, F. Mantovani, From intention to action: the role of presence, "New Ideas in Psychology" 2011, 29, 1, s. 24-37. 
ścią działania i doświadczania. Im bardziej podmiot jest zdolny do uaktywnienia swoich intencji na rzecz realizacji działania, tym bardziej czuje się obecny. Dlatego, autorzy sugerują, aby uczucie obecności traktować jako to, co dostarcza, na zasadzie sprzężenia zwrotnego, ,ja" (self) informacji o statusie jego aktywności (działalności). „Ja” percypuje zmiany w uczuciu obecności i dostosowuje odpowiednio do niego swoją aktywność ${ }^{17}$. To z tego powodu uczucie obecności (intuicyjna percepcja pomyślnie uaktywnianych intencji podmiotu) nie jest czymś oddzielnym od doświadczenia podmiotu, ale jest bezpośrednio z nim związane ${ }^{18}$.

Obecność i samoobecność, wskazując na podmiotowość aktów intencjonalnych oraz podmiotową sprawczość, są czymś kluczowym dla filozofii personalistycznej. Na przykład John F. Crosby podkreśla

[...] intencjonalność zaś lub skierowanie się na przedmiot lub transcendowanie siebie stanowi fundamentalny wymiar świadomości osobowej [...]. Zwracając się ku przedmiotowi poza mną samym zwracam się jako ktoś, kto jest świadomie zakotwiczony w sobie. Owo wyjście na zewnątrz aktu intencjonalnego jest zakotwiczone w wewnętrzności mojego bycia osobowego. Ja, który zwracam się ku przedmiotowi, w tym zwróceniu się jestem obecny sam przed sobą. Bez względu na to, jak bardzo pogrążam się w przedmiocie mojego czynu, nie mogę nigdy zatracić całkowicie swojej samoobecności. Moja świadomość „czegoś” nie może całkowicie wyprzeć mojej samoobecności. Właśnie pod pojęciem tego związku mnie z samym sobą jako podmiotem, związku stanowiącego wewnętrzność mojego istnienia i działania, rozumiem podmiotowość świadomości ${ }^{19}$.

W innym miejscu tenże autor dodaje „im silniejsza moja samoobecność, tym głębiej mogę wejść w przedmiot poza mną; moja samooobecność nie rywalizuje $\mathrm{z}$ moją transcendencją ku temu przedmiotowi, lecz raczej sprawia, że staje się ona możliwa i doskonali ją"20. Wyjaśnijmy, autor w obrębie podmiotowości ludzkiej wyróżnia dwa fundamentalne wymiary - samoobecność osoby oraz autodeterminację lub wolność podmiotową osoby.

Poza wskazaniem na podstawowe znaczenie poczucia podmiotowości i na ,ja" podmiotowe w kreowaniu działań (lub szerzej, zachowań) nieco odrębną kwestią jest wymiar wolności wyboru aktów działania.

W sensie szerokim wykonawcza funkcja ,ja” (w zakres której wchodzą wszystkie akty kontrolowania lub zmiany ,ja” i wszystkie akty decyzyjne, inicjujące) często zależy od jego zasobów. Te zasoby można sprowadzić do siły lub energii. Jeśli ,ja” wykona wysiłek, jak np. przeciwstawianie się pokusom, poja-

${ }^{17}$ Tamże, s. 29

${ }^{18}$ Tamże, s. 30.

${ }^{19}$ J.F. Crosby, Zarys filozofii osoby. Bycie sobq, Kraków 2007, s. 101.

${ }^{20}$ Tamże, s. 102. 
wia się tendencja do bycia osłabionym (wyczerpania ,ja”). Jest to po prostu stan zmniejszenia wolicjonalnych zasobów. Eksperymenty uzasadniają powyższe przewidywania $^{21}$.

Również wcześniej wymieniana zgodność (poziom kongruencji) pomiędzy ukrytymi i jawnymi motywami determinuje wielkość wolicjonalnej samokontroli wymaganej do wdrożenia intencji w działanie. Wysoki poziom zbieżności nie wymaga specjalnych wysiłków, niski poziom zbieżności prowadzi do zwiększonego wysiłku przy przechodzeniu od intencji do działania ${ }^{22}$. Jest to zgodne $z$ interpretacjami innych autorów wskazujących na konsekwencje zbieżności dla samopoczucia - kongruencja prowadzi do dobrego samopoczucia. H.M. Kehr ${ }^{23}$ dowodzi, że chroniczne rozbieżności pomiędzy ukrytymi i jawnymi motywami prowadzą do wolicjonalnego osłabienia (wyczerpania). W tym względzie występują jednak istotne indywidualne różnice.

Pomija się tutaj inne istotne propozycje, jak np. Carla Ransona Rogersa, który wskazywał na podstawowe znaczenie kongruencji ,ja" z linią samorealizacyjną wyznaczaną przez organizm ${ }^{24}$. Dążenie do samorealizacji można w powyższym świetle traktować jako motyw ukryty - zatem zbieżność motywów jawnych z motywami ukrytymi staje się jakąś formą wyjaśniania mechanizmów rozwoju. Zbieżność pomiędzy własnymi potrzebami a wyznaczanymi czy wypływającymi z nich celami, wartościami, podnosi poczucie bycia sprawcą. Podkreśla to też teoria zgodności z ,ja” (self-concordance) Kennona M. Sheldona i Andrewa J. Elliota ${ }^{25}$. Cele harmonijne z posiadanymi potrzebami, zainteresowaniami, uwewnętrznionymi wartościami reprezentują to, co autorzy propozycji nazywają celami zgodnymi z ,ja”. Ta zgodność przyczynia się do integracji i podniesienia sprawczości działań ,ja”. Z kolei cele narzucone przez otoczenie i uwewnętrznione przez podmiot stają się formą powinności, natomiast cele zewnętrzne (za realizację których można być pochwalonym lub skarconym) niezharmonizowane z potrzebami jednostkowymi mogą prowadzić do stanu dezintegracji (jest to sytuacja niezgodności z ,ja”). Cele zgodne z ,ja” generują większy wysiłek na rzecz ich realizacji niż cele niezgodne $\mathrm{z}$,ja”. Ponadto ich osiąganie wiąże się $z$ większą satysfakcją, a to dalej wzmacnia poczucie sprawstwa i sprzyja generalnie dobremu samopoczuciu. Cele niezgodne $\mathrm{z}$, ,ja" prowadzą natomiast do osłabienia poczucia sprawstwa i wzmacniają poczucie nacisku i przymusu ze

\footnotetext{
${ }^{21}$ Por. R.F. Baumeister, M. Muraven, D.M. Tice, Ego depletion: a resource model of volition, self-regulation, and controlled processing, "Social Cognition" 2000, 18, 2, s. 130-150.

${ }^{22}$ Motivation and action, red. J. Heckhausen, H. Heckhausen, Cambridge 2012, s. 422.

${ }^{23}$ Za: tamże.

${ }^{24}$ C.R. Rogers, On becoming a person. A therapist's view of psychotherapy, Boston 1961; tenże, Some observations on the organization of personality, w: Personality. Selected readings, red. R.S. Lazarus, E.M. Opton, Harmondsworth 1967, s. 103-122.

${ }^{25}$ Za J. Reeve, Understanding motivation and emotion, New York 2005, s. 283-286.
} 
strony otoczenia, generując bardzo często uczucia niepokoju. Tak więc podmiotowe ,ja” osób, u których mamy do czynienia ze zgodnością celów z ,ja”, będzie bardziej proaktywne i inicjatywne, prowadząc do coraz to wyraźniejszego rozwoju posiadanych potencjałów. Powyższe jest zgodne z „duchem” interpretacji teorii samorealizacji (np. Charlotte Buhler, Abraham Maslow, Carl Rogers) czy psychoanalizy humanistycznej (np. Erich Fromm).

Pokrótce wzmiankowane analizy i wnioski z nich płynące lub uzasadniające możliwość odwołania się do ,ja" podmiotowego są istotne. I w tym artykule chodzi o to, aby nie analizując sytuacyjnych mechanizmów pozwalających na wolne wybory, ukazać, co prowadzi do lepszej dyspozycyjności w kreowaniu i podejmowaniu działań wskazujących na wolność człowieka. Dlatego też ważne staje się zrozumienie uwarunkowań stanowiących o dyspozycji do bycia wolnym. Czym innym stanie się jednak w danej sytuacji akt wolności woli. Na początku jednak jeszcze kilka uwag na temat zasadności przyjęcia personalistycznej perspektywy interpretacji.

\section{OSOBA KLUCZEM DO ZROZUMIENIA WOLNOŚCI - PERSPEKTYWA PERSONALISTYCZNA}

Kluczowe znaczenie dla zrozumienia ludzkiej motywacji mają tzw. motywy „ja” (m.in. dążenie do tożsamości, utrzymania wartości, twórczości itd.) - por. szersze analizy prezentowane $\mathrm{w}$ innym miejscu ${ }^{26}$. To one pozwalają wnioskować o odmienności czy specyfice ludzkiego bytu. One też mogą być jednym z argumentów pozwalających wnioskować o rodzajach atrybutów, jakie można przypisać osobie. Innymi słowy, „motywy ja” stanowią podstawę do poszukiwania takiego określenia ich nosiciela, które oddałoby jego oryginalność. Proponowanym określeniem jest „osoba”. Określenie „osoba”, „bycie osobą” wskazuje też i na to, że człowiek z urodzenia jest osobą. Człowiek nie staje się osobą, on nią jest. Bycie $\mathrm{z}$ urodzenia osobą oznacza posiadanie potencjału lub możności zachowania się w sposób określony przez atrybuty przysługujące osobie (jak np. rozumność, wolność, odpowiedzialność).

Definicji osoby jest bardzo wiele ${ }^{27}$, a sam problem osoby, szczególnie w psychologii, jest co najmniej kłopotliwy ${ }^{28}$. Za Mieczysławem Albertem Krąpcem ${ }^{29}$

${ }^{26}$ H. Gasiul, Teorie emocji i motywacji, Warszawa 2007; tenże, Psychologia osobowości. Nurty, teorie, koncepcje, Warszawa 2012; tenże, Czy powrót do psychologii personalistycznej jest możliwy i jak mógłby być uzasadniony? „Czasopismo Psychologiczne” 2012, 18, 2, s. 347-360.

${ }_{27}$ S.C. Bartnik, Szkice do systemu personalizmu, Lublin 2006; tenże, Personalizm, Lublin 2008; J. Bremer, Osoba - fikcja czy rzeczywistość? Tożsamość i jedność. Ja w świetle badań neurologicznych, Kraków 2008; B. Gacka, Personalizm amerykański, Lublin 1996; S. Kowalczyk, $Z$ refleksji nad człowiekiem. Człowiek - społeczność - wartość, Lublin 1995; tenże, Nurty personalizmu. Od Augustyna do Wojtyly, Lublin 2010. 
przyjęto tutaj, że osoba jest „konkretem, jednostkową substancjalną i dynamiczną całością, świadomą siebie samej, podlegającą ciągłemu rozwojowi i doskonaleniu". Osoba jako jednostkowa substancja jest zarazem otwarta ku innym, jest „bytem dla drugiego".

Odwoływanie się do pojęcia osoby jest raczej nawiązywaniem do antropologii personalistycznej i nie jest stricte związane z ideą właściwą dla psychologii personalistycznej. Personalizm bowiem, jak podkreśla Czesław Bartnik ${ }^{30}$, to „kierunek myśli nawiązujący do osoby jako rzeczywistości o statusie najbardziej szczególnym, najwyższej i transcendującej wszystko inne", natomiast dążenie do definicji pojęcia osoby i wyróżnienia atrybutów osobowych jest zadaniem antropologii personalistycznej. Autorowi prezentowanego opracowania również bliższa jest perspektywa antropologii personalistycznej - jak się zdaje - jest to najczęściej wybierana przez psychologów ścieżka prowadząca do idei personalizmu; najpierw ważne jest określenie właściwości, a na bazie tych właściwości dojście do przyjęcia kategorii najbardziej oddającej specyfikę ich posiadacza. Chwytając i opisując atrybuty (właściwości), jednocześnie chwytamy specyfikę bytu ludzkiego, a jak specyfikę, to i podstawowe przyczyny decydujące o zachowaniu się człowieka.

Tutaj może pojawiać się zarzut powrotu do esencjonalizmu lub substancjalizmu - współcześnie bowiem w psychologii ,ja” raczej jest interpretowane w duchu konstruktywizmu, postmodernizmu lub interakcjonizmu symbolicznego (lub jako ja relacyjne). Niewątpliwie jednak podmiotowość i bycie podmiotem nie pozwala na lekceważenie substancjalności. „Ja” jako intencjonalny, sprawczy podmiot uczestniczy w każdym akcie działania, bo ten akt działania przynależy do kogoś i przez tego kogoś jest wykonywany. A to, że „ja” staje się jakieś i tylko może stawać się w ogóle i w szczególności jakieś, wynika z relacyjności, dialogowości z innymi, a w szczególności ze sposobu spełniania się tzw. motywów ,ja”. Choć bowiem „motywy ja” są ze swej istoty egotyczne, to jednak ich realizacja zawsze wymaga relacji z innymi (np. nie da się podnieść czy utrzymać poczucia własnej wartości inaczej jak poprzez odniesienie i więź z innymi - por. np. zjawisko Michała Anioła ${ }^{31}$ ).

Na rodzaj właściwości (atrybutów) przynależnych osobie wskazują kategorie czy rodzaje motywów ,ja”. Analizy psychologiczne pozwalają na wyróżnienie następujących kluczowych, jak się zdaje, „motywów ja”: (a) motywu dążenia do

${ }^{28} \mathrm{~K}$. Krzyżewski, O statusie i funkcjonowaniu kategorii „osoba“ $w$ koncepcjach psychologicznych, „Przegląd Psychologiczny” 1990, XXXIII, 1, s. 69-76.

${ }_{29}^{2}$ M. Krapiec, Ja-człowiek. Zarys antropologii filozoficznej, Lublin 1974, s. 289.

${ }^{30}$ S.C. Bartnik, Szkice do systemu personalizmu, Lublin 2006, s. 41.

${ }^{31}$ S.M. Drigotas, The Michelangelo phenomenon and personal well-being, "Journal of Personality" 2002, 70, 1, s. 59-77; H. Gasiul, Teorie emocji i motywacji, Warszawa 2007, s. 440-442. 
zrozumienia i samoświadomości (kluczowego w analizach nurtu poznawczego); (b) motywu dążenia do tożsamości i określenia tożsamości (indywidualnej, publicznej, narodowej); (c) motywu dążenia do zachowania podmiotowości, kierowania sobą, możliwości wyboru (czy wolności - kluczowe znaczenie podkreślane przez psychologię egzystencjalna); badania nad poczuciem kompetencji i skuteczności; (d) motywu dążenia do przypisania sobie samemu sprawstwa i odpowiedzialności za własne zachowania; (e) motywu dążenia do twórczego rozwoju, przekraczania stanów tu i teraz na rzecz stanów przyszłych (zdolność do transcendencji, transgresji); (f) motywu dążenia do zachowania własnej godności, wartości samego siebie (zarówno dla samego siebie, jak i w oczach innych osób) - psychologia motywów związanych z ,ja"; (g) motywu dążenia do zachowania intymności (prywatności) świata wewnętrznego - analizy nad zjawiskiem podmiotowości ludzkiej (wcześniej sygnalizowane). Motywy te (oczywiście jest to próba wyróżnienia jawiących się, w opinii autora tego opracowania, podstawowych motywów) rejestrowane na poziomie analiz psychologicznych mogą być dalej wskazaniem nie tylko na specyfikę ludzkiego bytu, zawartą w określeniu „osoba”, ale i na atrybuty przysługujące osobie. Jest to coś (ktoś), o czym wnioskujemy, a co jest jednocześnie podstawą, z jakiej dalej staje się możliwe przewidywanie i interpretacja jednostkowych zachowań oraz osobowości. Innymi słowy, „motywy ja" wskazują na atrybuty osobowe, do których można zaliczyć odpowiednio: (a) rozumność i świadomość siebie samego; (b) tożsamość i ciagłość (lub podmiotowość, bycie sprawca); (c) wolność i intencjonalność; (d) odpowiedzialność; (e) twórczość (transcendentność); (e) godność oraz (g) intymność, prywatność (wymiar odrębności siebie i stanowienia o sobie).

Biorąc pod uwagę wcześniejsze tutaj prezentowane analizy oraz wskazaną jako zasadną perspektywę personalistyczną, należy stwierdzić, że kluczem do zrozumienia wolności jest to, co jest $\mathrm{w}$ osobie, co z niej płynie i co daje szansę na spełnianie się jej.

W tym też świetle nieco inaczej przedstawia się możliwość zrozumienia procesów wolicjonalnych i problem wolności osoby. Spełnianie się motywów ,ja” prowadzi do integracji wewnętrznej i tworzy podstawy rozwoju poczucia podmiotowości oraz bycia podmiotem. Taka harmonia czyni człowieka wolnym i pozwala na korzystanie $z$ wolności oraz na wzrost siły woli.

Inaczej jeszcze, poprzez realizację atrybutów osobowych (podtrzymywanie godności, tożsamości itd.) następuje jednoczesna sposobność do stawania się podmiotem i odczuwania bycia dysponentem wyboru - a to oznacza wolność osoby. Jeśli motywy ,ja” są szczególnym, najważniejszym i w jakiejś mierze najgłębszym źródłem podejmowanych aktywności, to ich frustracja prowadzi do osłabienia ,ja” (osłabienia ,ja” - o którym wyżej wspominano) i obniżenia poczucia podmiotowości, a tym samym do ograniczenia poczucia wolności wyboru lub samego aktu woli. 
Zgodnie z wcześniej wprowadzonym podziałem motywami ukrytymi byłyby, patrząc z perspektywy personalistycznej, motywy ,ja” (atrybuty osobowe), natomiast motywami jawnymi podejmowane i uświadamiane przez podmiot wybory, intencje, działania (one byłyby „wskaźnikiem” sposobu realizacji motywów ukrytych). Takie definiowanie motywów ukrytych nie za bardzo jest zgodne ze sposobem ich pojmowania prezentowanym wcześniej przez Kuhla. Raczej jest ono bliższe sposobom rozumienia motywów ukrytych przez psychologów organicystycznych (np. James Angell, Abraham Maslow, Carl Rogers) oraz niektórych psychologów pozostających poza dominującymi trendami myślenia w kategoriach poznawczo-społecznych, jak np. Hubert J.M. Hermans (wymienia on dwa ukryte motywy, motyw dążenia do umacniania samego siebie oraz motyw dążenia do kontaktu z innymi, których spełnienie sygnalizowane jest doświadczanymi stanami uczuciowymi, traktowanymi jako motywy jawne ${ }^{32}$ ).

\section{WOLNOŚĆ Z PERSPEKTYWY ETAPÓW ROZWOJU OSOBY}

Na wolność woli można też spojrzeć z punktu widzenia etapów rozwoju człowieka. Wielu teoretyków wskazuje na to, że w rozwoju człowieka można wyróżnić dwa główne etapy kształtowania się osobowości - z których pierwszy miałby charakter etapu przystosowania i odpowiadałby za rozwój fundamentów, natomiast drugi byłby odkrywaniem indywidualnego rysu zgodnego z dyspozycjami osobowościowymi ${ }^{33}$. Na etapie przystosowania człowiek uczy się nowych umiejętności, nowych strategii i sposobów radzenia sobie z różnymi aspektami życia - świadomość wartości i sens w istotnej mierze zależą wtedy od uznawanych autorytetów oraz od jakości interakcji z nimi spełniającej najgłębsze motywy wypływające z atrybutów osobowych. Osiaganie umiejętności, zdolność do rozwoju kompetencji daje coraz to wyraźniejsze nie tylko poczucie wolności, ale człowiek coraz to wyraźniej staje się wolny. W psychologii są też podejścia wiążące kilka elementów jako wyjaśniających wolność woli. Trzy elementy są tutaj kluczowe: postrzegane umiejscowienie kontroli, wola (uczucie wolności) oraz postrzegany wybór. Postrzegane poczucie umiejscowienia kontroli oznacza swego rodzaju kontinuum od poczucia własnej inicjatywy do wykonywania działań, do poczucia zewnętrznego źródła działań. Wola jest niewymuszoną chęcią zaangażowania się w działanie, natomiast postrzegany wybór odnosi się do poczucia

${ }^{32}$ Por. H.J.M. Hermans, E. Hermans-Jansen, Autonarracje. Tworzenie znaczeń w psychoterapii, Warszawa 2000.

${ }^{33}$ E.F. Edinger, Ego and archetype, Boston 1992; V.E. Frankl, Homo patiens, Warszawa 1984; C.G. Jung, Aion, Przyczynki do symboliki jaźni, Warszawa 1997; C.S. Hall, G. Lindzey, Teorie osobowości, Warszawa 1990, s. 131-137; A. Nelicki, „Metakliniczna” koncepcja osoby V.E. Frankla, w: Klasyczne i wspótczesne koncepcje osobowości, red. A. Gałdowska, Kraków 1999, s. 177-194. 
doświadczania wyboru na własny sposób (jest przeciwne do poczucia obowiązku narzucanego przez otoczenie) $)^{34}$.

Dziecięca zdolność rejestracji rzeczywistości jest w istotnej mierze uzależniona od możliwości stwarzanych przez obiekt zapewniający poczucie wartości, tożsamości itd. Im bardziej znaczące osoby spełniają powyższe motywy, tym większe poczucie bezpieczeństwa i pewniejsze wychodzenie ku zewnętrznej rzeczywistości ${ }^{35}$. Odwoływanie się do zewnętrznych w stosunku do podmiotu obiektów (osób) oznacza też silniejszą zależność uczuciową od nich. Ale też to daje dziecku wolność - wolność od uwikłań negatywnych emocjonalnie, wolność od poczucia zagrożenia, wolność wychodzenia ku coraz to na nowo odkrywanym wymiarom rzeczywistości.

Patrząc nawet z perspektywy procesów samoregulacyjnych, w rozwoju różnic indywidualnych $\mathrm{w}$ zakresie wolicjonalnym i motywacyjnym istotne jest stopniowe przechodzenie od odpowiedzialności za regulowanie zachowaniami przez innych (na etapie dzieciństwa) do odpowiedzialności za regulowanie zachowaniami przez siebie samego. Podstawowe znaczenie ma relacja $\mathrm{z}$ rodzicami w okresie dzieciństwa - ona tworzy swego rodzaju fundament dla dalszego rozwoju - współczesne analizy to potwierdzają ${ }^{36}$. Wcześniej bardzo dużo miejsca poświęcały analizie relacji dziecko - osoby znaczące teorie relacji z obiektem, wskazując na wagę jakości tych relacji w rozwoju ego i self ${ }^{37}$.

Jutta Heckhausen, Richard Schulz i Carsten Wrosch ${ }^{38}$ proponują motywacyjną teorię rozwoju w trakcie życia, która wyjaśnia mechanizmy rozwoju samokontroli. Ujmuje ona proces dążenia do realizacji i przystosowania dalekosiężnych celów nie tyle jako efekt samoregulacji, ile jako rezultat zmagania się z kontrolą. Autorzy dowodzą, że rozwój mechanizmów regulacyjnych wymaga stale aktualizacji procesu, określanego jako metamotywacyjny, który umożliwia wybory celów i tym samym zapewnia osiaganie kontroli. ,[...] motywowane działanie jednostek w każdym wieku jest ograniczane przez podstawowe dążenie do wywierania kontroli nad otoczeniem (primary control striving). Potencjał podstawowej kontroli osiaggany w ciagu życia (tj. potencjał do kontrolowania zdarzeń w otoczeniu) jest postrzegany jako kryterium powodzenia rozwoju w ciagu życia”. Podstawowe dążenie do kontroli musi być skupione na pewnych

\footnotetext{
${ }^{34}$ J. Reeve, Understanding motivation and emotion, New York 2005, s. 106-107.

${ }^{35}$ Por. analizy w: J. Bowlby, Attachment and loss, vol. 1, New York 1969; J. Feeney, P. Noller, Adult attachment, Thousand Oaks 1996; Attachment in adults. Clinical and developmental perspectives, ed. M.B. Sperling, W.H. Berman, New York - London 1994.

${ }^{36}$ Por. Motivation and action, dz. cyt., s. 423.

${ }^{37}$ Szersze analizy: H. Gasiul, Czy powrót do psychologii personalistycznej jest możliwy i jak mógłby być uzasadniony?, „Czasopismo Psychologiczne” 2012, 18, 2, s. 286-302.

${ }^{38} \mathrm{Za}$ Motivation and action, dz. cyt., s. 421-422.
} 
wybranych celach. Co więcej, ponieważ warunki dążenia i osiagania celów zmieniają się w ciągu życia, cele, które są nieosiągalne albo niegodne, aby je realizować w stosunku do innych celów, muszą być dezaktywowane, pozwalając tym samym jednostce na skupienie się na realizacji celów zgodnych z możliwościami. Indywidualne różnice w różnych elementach rozwojowego procesu regulacji mogą wpływać zarówno na obiektywne (np. pozycję zawodową, status małżeński), jak i subiektywne (np. zdrowie psychiczne, równowagę emocjonalną) rezultaty rozwojowe. Ludzie różnią się między sobą w zakresie siły podstawowego dążenia do kontroli i woli zmagania się z dążeniem do osiaggania danych celów czy rezygnacji z niego. Poziom kontrolowalności, który jest brany przez daną osobę jako niezbędny dla zainicjowania podstawowego dążenia do kontroli, jest czymś kluczowym. Ludzie także różnią się, jeśli chodzi o tolerancję poziomu utraty kontroli w zakresie danej domeny (np. osiagnięć akademickich). Ponadto, prawdopodobnie istotne są też różnice indywidualne w zakresie wtórnych strategii kontroli motywacyjnej i wolitywnej regulacji. Badania nad dorosłymi w różnym wieku wskazują z jednej strony na różnice indywidualne w zakresie zbieżności pomiędzy celami i dążeniem do kontroli, a z drugiej na potencjalną dostępność kontroli w pewnym wieku. Jeśli dążenie do kontroli jest kongruentne z dostępnością potencjału kontroli, rezultaty rozwojowe są bardziej zadowalające, szczególnie w zakresie zdrowia psychicznego, równowagi emocjonalnej i samopoczucia.

W wyniku ukształtowania pewnych dyspozycji (jak np. umiejętności poznawczych) one same w sobie stanowią źródło oparcia dla dalszego wzrastania. Osiagnięcie powyższego może być jednocześnie traktowane jako sposobność wejścia na wyższy, drugi etap rozwoju - jest to etap właściwego rozwoju i nabywania indywidualnych cech świadomości. Ten etap rozwoju można porównać z przełomem w świadomości polegającym na odkrywaniu jaźni (ok. 40. roku życia), o którym mówił Carl Gustav Jung, lub z Franklowskim podziałem na etapy życia, gdzie pierwszy etap to dojrzewanie organizmu psychologicznego do bycia narzędziem, jak to określa Viktor Emil Frankl, osoby duchowej (kryterium jest możność przypisania osobie autonomicznej intencjonalności - działania muszą być sensowne i własne), natomiast drugi to właściwy rozwój osoby, który polega na realizowaniu tkwiących $\mathrm{w}$ osobie możliwości, na spełnianiu samego siebie $\mathrm{w}$ procesie samotranscendencji ${ }^{39}$. Innymi słowy, o ile pierwszy etap życia z uwagi na dominantę akcentów adaptacyjnych umożliwia realizację motywów ,ja" (atrybutów osobowych) poprzez podległość osobom znaczącym (one stanowią o ich spełnieniu - stąd jest to okres, w którym człowiek też może mieć świadomość, że jego akty zachowania będą nie do końca obciążone jego wyborami jest to okres raczej tendencji do obwiniania innych i bardziej przedmiotowego

\footnotetext{
${ }^{39}$ Por. V.E. Frankl, Wola sensu. Założenia i zastosowanie logoterapii, Warszawa 2010.
} 
traktowania innych), o tyle etap drugi jednak jest okresem indywidualnego odkrywania sposobów spełniania siebie jako osoby i tym samym osiagania zdolności korzystania z aktów woli oraz doświadczania wolności. Proponowaną interpretację można schematycznie przedstawić następująco:

\section{Schemat nr 1 - etapy rozwoju}

Etap przystosowania (uczenia umiejętności)

Osoba jest na pozycji bycia przedmiotem osobowym, gdyż

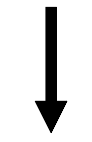

szuka innych dla swego spełnienia

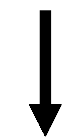

odkrywa sens (wartości) poprzez identyfikację z innymi

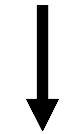

stopień, w jakim inni (znaczący dla rozwoju)

dają szansę spełniania siebie (pozwalają na utrzymanie godności, wolności, tożsamości itd.)

powyższe stanowi o warunkach pozwalających na bycie podmiotem ,wolnym” - następuje przejście do etapu indywidualnego

${ }^{40}$ Wydaje się, że rozwój osoby (a nie bycie osobą) polegałby na spełnianiu się atrybutów osobowych poprzez realizację motywów ,ja" (tj. na wzrastaniu w rozumności, wolności, odpowiedzialności itd.). A dalej, w zależności od sposobu i możliwości spełnienia się motywów ,ja” następuje możność realizacji tego, co stanowi potencjał osobowości danej jednostki. Sama w sobie osobowość to ujawniająca się w ciagu życia ludzkiego konfiguracja indywidualnych, niepowtarzalnych 


\section{UTRATA WOLI I WOLNOŚCI OSOBOWEJ JAKO EFEKT STAWANIA SIE PRZEDMIOTEM}

Bez względu jednak na okres życia zawsze u człowieka występuje dążenie do utrzymania stanu podmiotowości, który sprowadza się do poczucia spełniania motywów „ja” (czy inaczej, atrybutów osobowych). Brak spełniania siebie jako osoby prowadzi z reguły do poszukiwania takich stref rzeczywistości, które tworzą szansę na realizację tych motywów osobowych. Stąd też człowiek może, chcąc zyskać poczucie podmiotowości, poszukiwać stref zastępczych, przywracających tę podmiotowość - choćby iluzyjnie. Efektem powyższego procesu stanie się zbyt silne wikłanie, prowadzące do stawania się przedmiotem (staję się przedmiotem, gdy strefa „poza” uzależnia mnie niejako od siebie, tym samym dając mi poczucie wartości, tożsamości itd.; jest to analogicznie jak w uzależnieniu alkoholowym - alkohol iluzyjnie przywraca godność, tożsamość itd., ale człowiek alkoholik jest przedmiotem, a nie podmiotem). Można przypuszczać, że charakter rozwoju będzie również warunkowany jednostkowymi dyspozycjami, które prowadzić będą do wyboru najbardziej dogodnych dla utrzymania stanu podmiotowości form rzeczywistości.

Ciąg zdarzeń przyczyniających się do takiego stanu rzeczy można opisać w formie poniższych schematów, które kończą te krótkie analizy (nr 2 - ukazujący możność lub niemożność wejścia w etap „stawania się” i nr 3 - obrazujący mechanizm stawania się przedmiotem).

właściwości podmiotu, wyznaczających sposoby jego zachowania w różnych interakcjach społecznych, w stosunku do samego siebie oraz do różnych innych form rzeczywistości. Osobowość jest w ciagłym procesie stawania się i na podstawie powtarzalności pewnych sposobów postępowania można wnioskować o posiadanych jednostkowych cechach - choć ich przejawy są zawsze nieco inne u różnych osób i zależą od rodzaju interakcji, z jakimi ma do czynienia dana osoba. Warunkiem realizacji tego potencjału osobowościowego jest spełnianie się ,atrybutów osobowych” w interakcji z innymi. Na przykład, spełnianie się tożsamości, godności, wolności itd. w sposób możliwy i wyznaczany przez warunki panujace $w$ danych relacjach interpersonalnych, w danej społeczności, kulturze powoduje jednocześnie wydobycie innego potencjału osobowościowego i inną postać osobowości.

Można też powiedzieć, że osobowość jest „czymś”, co wynika z danej osoby i „przynależy” do danej osoby (określa daną osobę jako tę osobę). Spełnianie się atrybutów osobowych (motywów ,ja”) tworzy swego rodzaju podstawę rozwoju osobowości, której kształt dalej będzie zależał od wielu innych warunków (właściwości psychobiologicznych, rodziny, kultury, w jakiej dana osoba się rozwija itd.). Te warunki tworzą swego rodzaju osnowę (kontekst), w jakim ten potencjał może się realizować - efektem jest dlatego też odmienny rozwój osobowości. I choć faktem jest, że to jest płynne, zmienne - zmieniają się warunki sytuacyjne, społeczne, kulturowe itd., zmienia się sposób dojścia do realizacji motywów ,ja” (i realizacji tym samym atrybutów osobowych) - ale sam w sobie motyw jest czymś stałym (constans) właściwym „,naturze osobowej człowieka". 
Schemat $\mathrm{nr} 2$ - warunki stawania się przedmiotem lub podmiotem

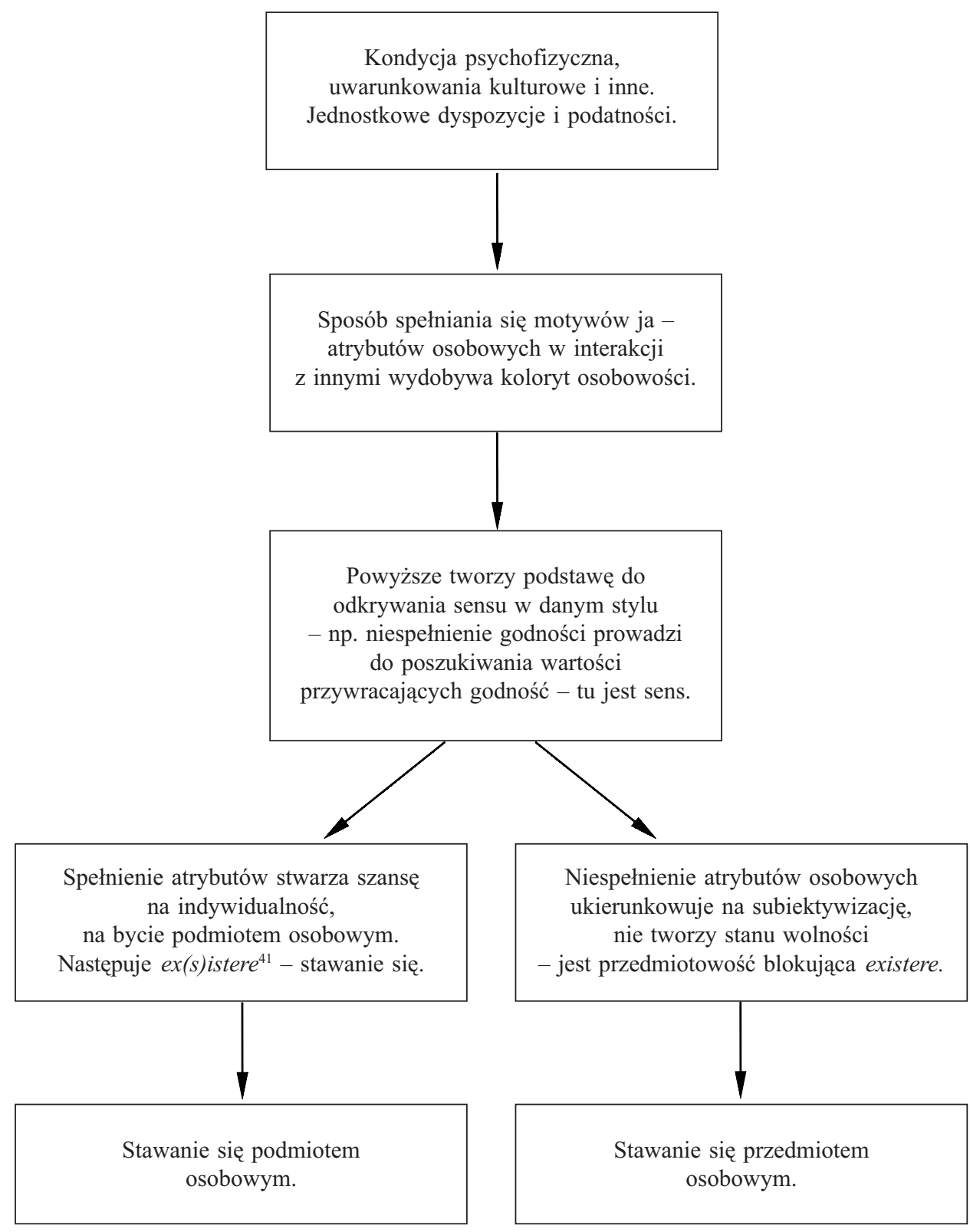

${ }^{41}$ Gwoli wyjaśnienia, słowo ex(s)istere jest różnie thumaczone. Najczęściej jako 'wystapić', 'zjawić się', 'stać się', 'istnieć' (za: W. Kopaliński, Słownik wyrazów obcych i zwrotów obcojęzycznych z almanachem, Warszawa 2000, s. 142). Tutaj potraktowano ex(s)istere jako 'stawanie się', 'wyłanianie się', 'wskazanie na człowieka jako wyłaniającego się, stającego się, egzystującego’ (za: R. May, O istocie człowieka. Szkice z psychologii egzystencjalnej, Poznań 1995, s. 58-59). 
Schemat nr 3 - zdarzenia prowadzące do obniżenia wolności osoby

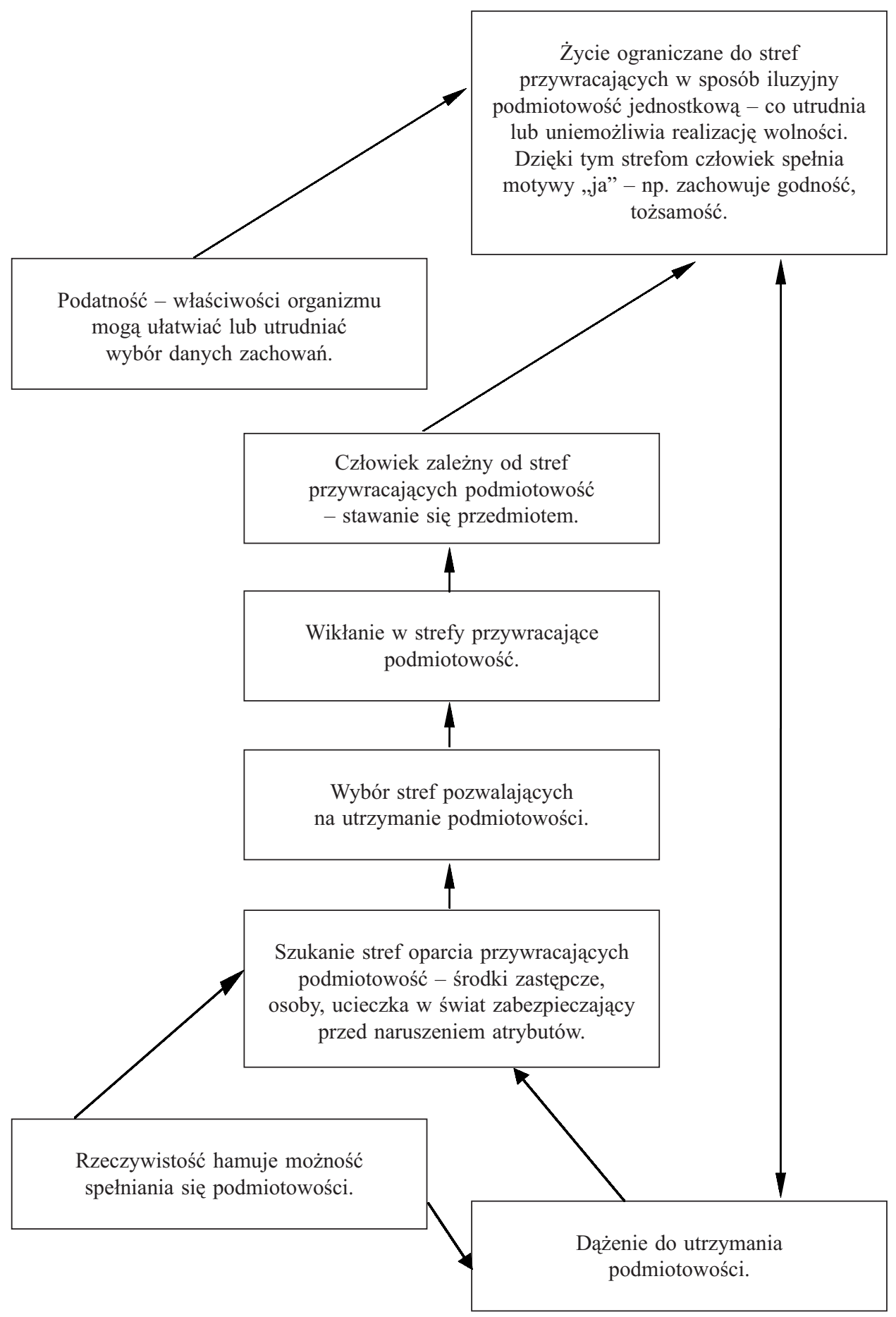


$\mathrm{W}$ pewnej harmonii z tutaj prezentowanymi wywodami pozostaje tzw. eudajmoniczna teoria tożsamości. W tej teorii wskazuje się na to, że u człowieka podstawowe jest dążenie do tworzenia „daimonion”, prawdziwego ,ja”, czyli tych potencjałów w każdej indywidualności, które reprezentują to, co jest najlepsze i co dana osoba jest w stanie zrealizować. „Życie w prawdzie do daimonion” prowadzi do szczególnej formy szczęścia, określonego jako eudajmonia - co też w psychologii może być określone jako uczucia osobowej siły wyrazu (feelings of personal expressiveness). Celem formacji tożsamości jest odkrywanie natury własnego daimonion, co obejmuje: (a) odkrywanie osobistych potencjałów; (b) wybór własnych celów (zamierzeń) życiowych; (c) znajdywanie sposobności do urzeczywistniania tych potencjałów i zamierzeń w realnym życiu ${ }^{42}$. Daimonion jest dany każdemu i wraz ze swoimi zdolnościami musi być rozwijany. Daimonion to naturalna funkcja, która ma siłę opanowania całej osoby. Może on być kreatywny bądź destruktywny lub zarówno kreatywny, jak i destruktywny - tak twierdzi R. May ${ }^{43}$.

\section{ZAKOŃCZENIE}

Na zakończenie warto podkreślić, że wolność woli, choć dotyczy bezpośrednio podmiotu, nie jest sprawą tylko samego podmiotu. $Z$ jednej strony wolność to zmaganie się samego człowieka z różnymi trudnościami życia ${ }^{44}$, a z drugiej jak pisze Józef Kozielecki ${ }^{45}$ - „,wolność to potencjalna transgresja, a transgresja to urzeczywistniona wolność". Wolność podmiotu kreuje się w relacji z innymi, którzy mogą spełniać motywy ,ja" (atrybuty osobowe), a ponieważ to właśnie motywy ,ja” świadczą o specyfice bytu osobowego i wskazują na „najgłębsze” źródła - przyczyny motywowanego zachowania, ich spełnienie poprzez interakcję z drugą osobą buduje fundament pod rozwój woli i jej wolności. I im bardziej są one spełniane, tym bardziej człowiek jest dysponowany do bycia wolnym podmiotem i dokonywania wolnych jednostkowo wyborów. Tak więc osoba, choć jest niepodzielną jednością (całościa), może tym bardziej stawać się osobą niepowtarzalną, im bardziej jest identyfikowana poprzez spełnianie motywów

42 A.S. Waterman, Eudaimonic identity theory: identity as self-discovery, w: Handboook of identity theory and research, red. S.J. Schwartz, K. Luyckx, V.L. Vignoles, New York 2011, vol. 1, s. 357.

${ }^{43}$ R. May, O istocie człowieka. Szkice z psychologii egzystencjalnej, Poznań 1995.

${ }^{44}$ Por. E. Fromm, Niech się stanie czlowiek. Z psychologii etyki, Warszawa - Wrocław 1994; tenże, Mieć czy być?, Poznań 1997; tenże, Ucieczka od wolności, Warszawa 2011; R. May, O istocie człowieka. Szkice z psychologii egzystencjalnej, Poznań 1995; analizy w: Wprowadzenie do psychologii egzystencjalnej, red. M. Opoczyńska, Kraków 1999; P. Tillich, Męstwo bycia, Poznań 1994.

45 J. Kozielecki, Człowiek wielowymiarowy, Warszawa 1996, s. 191. 
„ja” w drugiej - innej osobie. Można powiedzieć, że dzięki powyższemu następuje sposobność do harmonizowania motywów ukrytych (tutaj, w perspektywie personalistycznej, motywami ukrytymi są motywy ,ja”) z motywami jawnymi co zapobiega osłabieniu ego, ułatwia przebieg samoregulacyjnych procesów i daje też możliwości rozwoju ku pełnemu stawaniu się sobą - daną osobą.

\section{BIBLIOGRAFIA}

Bandura A., Exercise of human agency through collective efficacy, w: The Personality Reader, red. M.W. Schustack, H.S. Friedman, Boston 2008, s. 190-194.

Barresi J., Moore C., Intentional relations and social understanding, "Behavioral and Brain Sciences" 1996, 19, 1, s. 107-154.

Bartnik S.C., Szkice do systemu personalizmu, Lublin 2006.

Bartnik S.C., Personalizm, Lublin 2008.

Baumeister R.F., Muraven M., Tice D.M., Ego depletion: a resource model of volition, self- regulation, and controlled processing, "Social Cognition" 2000, 18, 2, s. 130-150.

Bowlby J., Attachment and loss, vol. 1, New York 1969.

Bremer J., Osoba - fikcja czy rzeczywistość? Tożsamość i jedność. Ja w świetle badań neurologicznych, Kraków 2008.

Crosby J.F., Zarys filozofii osoby. Bycie soba, Kraków 2007.

Dannefer D., Freedom isn't free. Power, alienation, and consequences of action, w: Action \& self-development. Theory and research through the life span, red. J. Brandtstadter, R.M. Lerner, Thousand Oaks 1999, s. 105-131.

Drigotas S.M., The Michelangelo phenomenon and personal well-being, "Journal of Personality", 2002, 70, 1, s. 59-77.

Edinger E.F., Ego and archetype, Boston 1992.

Feeney J., Noller P., Adult attachment, Thousand Oaks 1996.

Frankl V.E., Homo patiens, Warszawa 1984.

Frankl V.E., Wola sensu. Założenia i zastosowanie logoterapii, Warszawa 2010.

Fromm E., Niech się stanie człowiek. Z psychologii etyki, Warszawa-Wrocław 1994.

Fromm E., Mieć czy być?, Poznań 1997.

Fromm E., Ucieczka od wolności, Warszawa 2011.

Gacka B., Personalizm amerykański, Lublin 1996.

Gasiul H., Teorie emocji i motywacji, Warszawa 2007.

Gasiul H., Psychologia osobowości. Nurty, teorie, koncepcje, Warszawa 2012.

Gasiul H., Czy powrót do psychologii personalistycznej jest możliwy i jak mógłby być uzasadniony?, „Czasopismo Psychologiczne” 2012, 18, 2, s. 347-360.

Haggard P., Human volition: towards a neuroscience of will, "Nature" 2008, 9, s. 934$-946$. 
Hall C.S., Lindzey G., Teorie osobowości, Warszawa 1990.

Heckhausen J., Heckhausen H. (ed.), Motivation and action, Cambridge 2012.

Hermans H.J.M., Hermans-Jansen E., Autonarracje. Tworzenie znaczeń w psychoterapii, Warszawa 2000.

Jackson T., Mackenzie J., Hobfoll S.E., Communal aspects of self-regulation, w: Handbook of self-regulation, ed. M. Boekaerts, P.R. Pintrich, M. Zeidner, San Diego 2000, s. 275-300.

Jung C.G., Aion, Przyczynki do symboliki jaźni, Warszawa 1997.

Kopaliński W, Stownik wyrazów obcych $i$ zwrotów obcojęzycznych $z$ almanachem, Warszawa 2000.

Kowalczyk S., Z refleksji nad człowiekiem. Człowiek - społeczność - wartość, Lublin 1995.

Kowalczyk S., Nurty personalizmu. Od Augustyna do Wojtyty, Lublin 2010.

Kozielecki J., Człowiek wielowymiarowy, Warszawa 1996.

Krapiec M., Ja-człowiek. Zarys antropologii filozoficznej, Lublin 1974.

Krzyżewski K., O statusie i funkcjonowaniu kategorii „osoba” w koncepcjach psychologicznych, „Przegląd Psychologiczny” 1990, XXXIII, 1, s. 69-76.

Kuhl J., Individual differences in self-regulation, w: Motivation and action, ed. J. Heckhausen, H. Heckhausen, Cambridge 2012, s. 300-328.

Mascolo M.F., Fischer K.W., Neimeyer R.A., The dynamic codevelopment of intentionality, self, and social relations, w: Action \& self-development. Theory and research through the life span, ed. J. Brandtstadter, R.M. Lerner, Thousand Oaks 1999, s. 133-166.

Maslow A.H., W strone psychologii istnienia, Warszawa 1986.

May R., Psychologia i dylemat ludzki, Warszawa 1989.

May R., O istocie człowieka. Szkice z psychologii egzystencjalnej, Poznań 1995.

Nelicki A., „Metakliniczna” koncepcja osoby V.E. Frankla, w: Klasyczne i współczesne koncepcje osobowości, red. A. Gałdowska, Kraków 1999, s. 177-194.

Obuchowski K., Człowiek intencjonalny, Warszawa 1993.

Oleś P., Wprowadzenie do psychologii osobowości, Warszawa 2003.

Opoczyńska M. (red.), Wprowadzenie do psychologii egzystencjalnej, Kraków 1999.

Pacherie E., The phenomenology of action: a conceptual framework, "Cognition" 2008, 107, s. 179-217.

Reeve J., Understanding motivation and emotion, New York 2005.

Rheinberg F., Psychologia motywacji, Kraków 2006.

Riva G., Waterworth J.A., Waterworth E.L., Mantovani F., From intention to action: the role of presence, "New Ideas in Psychology" 2011, 29, 1, s. 24-37.

Rogers C.R., On becoming a person. A therapist's view of psychotherapy, Boston 1961.

Rogers C.R., Some observations on the organization of personality, w: Personality. Selected readings, ed. R.S. Lazarus, E.M. Opton, Harmondsworth 1967, s. 103-122. 
Sperling M.B., Berman W.H. (red.), Attachment in adults. Clinical and developmental perspectives, New York-London 1994.

Tillich P., Męstwo bycia, Poznań 1994.

Waterman A.S., Eudaimonic identity theory: identity as self- discovery, w: Handboook of identity theory and research, ed. S.J. Schwartz, K. Luyckx, V.L. Vignoles, vol. 1, New York 2011, s. 357-379.

Zhu J., Intention and volition, "Canadian Journal of Philosophy” 2004, 34, 2, s. 175-194.

\section{SUMMARY}

It is an attempt to show how the contemporary psychology interprets the volition acts and the problem of freedom of will. The author tries to determine what conditions are necessary in order to develop the skillfulness of the will and its freedom. Some psychologists try to avoid the notion of will, some others use it together with the notion of decision and intention, subject and person. Freedom of will can increase or decrease.

\section{Keywords}

will, freedom, self- motives, personalistic perspective

\section{Słowa kluczowe}

wola, wolność, własne motywy, perspektywa personalistyczna 